\title{
Pembelajaran Menulis Teks Anekdot dengan Menggunakan Metode Discovery Learning
}

\author{
Teti Sobari $^{\mathrm{a}, \mathrm{b}, 1}$ dan Mutiara Ramadhan ${ }^{\mathrm{a}, 2}$ \\ ${ }^{a}$ IKIP Siliwangi, Cimahi, Indonesia

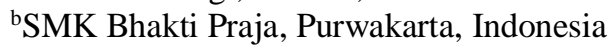 \\ ${ }^{1}$ sobariteti@gmail.com; ${ }^{2}$ mutiararamadhan9@gmail.com
}

\begin{tabular}{ll} 
Article info & A B S T R A C T \\
\hline Article history: & One of the texts used in language learning is anecdotal text. This \\
Revised : $01-05-2019-2020$ & study aims to improve students' knowledge and skills on anecdotal \\
Accepted: 28-09-2020 & text material. This research was conducted in two cycles, each of \\
& which consisted of two meetings. The stages in this research \\
& consist of planning, implementing, and reflecting. The method in \\
& this research is Classroom Action Research. Subjects taken in this \\
& study were all students of class X Multimedia 1 SMK TI Garuda \\
& Nusantara Cimahi. Based on the research results obtained, it can \\
& be concluded that the level of difficulty of the learning material \\
& can affect student outcomes. This can be seen from the assessment \\
& of students' knowledge skills, which are better than writing skills. \\
& Learning using the discovery learning method can increase \\
& students 'knowledge of anecdotal texts and improve students' \\
& ability to write anecdotal texts.
\end{tabular}

Keywords: anecdotal texts discovery learning lesson study SMK
Salah satu teks yang digunakan pada pembelajaran bahasa adalah teks anekdot. Penelitian ini bertujuan untuk meningkatkan kemampuan pengetahuan dan keterampilan siswa pada materi teks anekdot. Penelitian ini dilakukan dalam dua siklus yang tiap siklusnya terdiri atas dua pertemuan. Tahapan dalam penelitian ini terdiri atas perencanaan, pelaksanaan, dan refleksi. Metode dalam penelitian ini adalah Penelitian Tindakan Kelas (PTK). Subjek yang diambil dalam penelitian ini adalah seluruh siswa kelas $\mathrm{X}$ Multimedia 1 SMK TI Garuda Nusantara Cimahi. Berdasarkan hasil penelitian yang diperoleh dapat disimpulkan bahwa tingkat kesulitan materi pembelajaran dapat memengaruhi hasil siswa. Hal tersebut dilihat dari penilaian kemampuan pengetahuan siswa lebih baik dibandingkan kemampuan menulis. Pembelajaran dengan menggunakan metode discovery learning dapat meningkatkan pengetahuan siswa mengenai teks anekdot serta meningkatkan kemampuan siswa dalam menulis teks anekdot.

Copyright $\odot 2020$ Institut Agama Islam Negeri Syekh Nurjati Cirebon.

\section{PENDAHULUAN}

Dalam pembelajaran Bahasa Indonesia, seorang anak harus memiliki empat keterampilan berbahasa. Keterampilan berbahasa tersebut meliputi menyimak, berbicara, membaca, dan menulis. Pada umumnya dari keempat keterampilan tersebut, menulis merupakan keterampilan berbahasa paling tinggi dan dianggap paling sulit di antara keterampilan berbahasa yang lain (Mulyaningsih, 2020). Hal ini sejalan dengan pendapat Azis (2012) yang menyatakan bahwa menulis merupakan kegiatan selangkah lebih maju guna memberdayakan potensi 
kreativitas siswa. Aktivitas ini sekaligus menghadirkan pengorganisasian. Kegiatan menulis memerlukan aktivitas yang berkaitan dengan cara berpikir seseorang. Sejalan dengan itu, Sobari (2012) menyatakan bahwa menulis dan berpikir terjalin sangat erat. Menulis merupakan sebuah proses komunikasi yang kompleks yang memungkinkan penulis untuk menggali pemikiran dan ide-idenya.

Berdasarkan hasil pengamatan di SMPN 2 Baranti Kab. Sidereng Rapang, siswa akan menulis apabila mendapat tugas dari guru. Bahkan kurang dari sepertiganya, siswa hanya menulis buku harian walaupun tidak rutin (Zain et al., 2017). Demikian juga berdasarkan hasil pengamatan, ditemukan kesulitan menulis yang dialami oleh siswa SMK di SMK TI Garuda Nusantara Cimahi khususnya dalam penulisan teks anekdot. Teks anekdot ialah cerita singkat yang menarik karena lucu dan mengesankan (Suherli, 2017). Teks anekdot merupakan salah satu materi pelajaran Bahasa Indonesia kelas X SMK pada kurikulum 2013 revisi. Materi tersebut tercantum dalam Kompetensi Dasar (KD) 3.5 dan 4.5 serta 3.6 dan 4.6. Dalam implementasinya, siswa cenderung mengalami kesulitan untuk menuangkan ide cerita dalam sebuah tulisan. Hal tersebut didukung oleh Sutaman dkk (dalam Dewy, 2016) yang menyatakan bahwa siswa mulai dari tingkat dasar hingga tingkat atas, belum mampu berbahasa Indonesia dengan baik dan benar, secara lisan maupun tulisan. Pernyataan di atas diperkuat dengan pendapat Tarigan (dalam Dewy, 2016) yang menyatakan bahwa pengajaran mengarang belum terlaksana dengan baik di sekolah.

Siswa juga mengalami kesulitan dalam membedakan teks anekdot dengan teks humor. Hal tersebut karena dalam kedua teks tersebut sangat kecil tingkat perbedaannya. Menurut Woi et al. (2019), kesulitan tersebut disebabkan oleh penyampaian makna pada teks anekdot dikemukakan secara tersirat dan juga siswa belum memahami bentuk dan fungsi implikatur. Kusnadi (2017) menyebutkan bahwa salah satu karakteristik teks anekdot adalah terdapat humor. Hal ini tidak terlepas dari tujuan teks anekdot yakni untuk menghibur dan sekaligus mengkritik orang atau suatu hal. Mulyadi dan Danaira (dalam Puspitasari \& Supriatna, 2017) mengemukakan bahwa teks anekdot merupakan sindiran mungkin juga berupa kritik, namun dinyatakan dalam bentuk humor. Sementara itu, Danandjaya (dalam Sholekah, 2016) berpendapat bahwa anekdot merupakan cerita dongeng yang mampu menimbulkan rasa menggelitik di hati sehingga dapat menimbulkan tawa bagi para pendengar ataupun pembaca (Rahmayanti et al., 2015). Teks anekdot adalah cerita pendek yang menarik karena lucu dan mudah diingat, biasanya tentang orang-orang penting atau terkenal dan berdasarkan pada peristiwa aktual (Permadi, 2018). Teks anekdot juga bisa berbentuk cerita khayalan yang bukan dari kejadian nyata atau cerita yang terinspirasi dari kejadian nyata (Agustina, 2020). Teks ini walau bersifat lucu dan mengesankan, tetapi mengandung makna tersirat dalam cerita tersebut. Biasanya makna yang tersiratnya berupa kritikan kepada tokoh-tokoh penting.

Oleh sebab itu, diperlukan suatu upaya dalam meningkatkan pengetahuan dan keterampilan siswa dalam pembelajaran teks anekdot. Upaya yang dapat dilakukan melalui penerapan metode discovery. Metode discovery ini merupakan salah satu metode yang dapat digunakan dalam proses pembelajaran untuk memajukan cara belajar yang lebih aktif dan berorientasi pada proses. Pernyataan di atas diperkuat oleh pendapat Sund (dalam Heriawan, 2012) yang menyatakan metode discovery adalah proses mental siswa mengasimilasi suatu konsep atau 
suatu prinsip. Proses tersebut dapat berupa mengamati, mengelompokkan, mengukur, dan membuat simpulan atas hasil pengamatan.

Indikator yang harus dimiliki oleh siswa dalam pembelajaran bahasa Indonesia pada teks anekdot, yakni: mendata pokok-pokok isi anekdot, mengidentifikasi penyebab kelucuan anekdot, membandingkan anekdot dengan humor, menganalisis kritik yang disampaikan dalam anekdot, mengidentifikasi struktur teks anekdot, mengenal berbagai pola penyajian anekdot, menceritakan kembali isi teks anekdot dengan pola penyajian yang berbeda, dan menyusun teks anekdot berdasarkan kajian yang menyangkut orang banyak atau perilaku seorang tokoh publik.

Beberapa penelitian sejenis mengenai menulis teks anekdot yaitu Wardani et al, hasil penelitiannya metode make a match dapat meningkatkan kemampuan menulis teks anekdot (2016). E. D. Wardani et al. (2018), anekdot sangat tepat digunakan dalam penyampaian karakter dan kearifan lokal karena humor yang disukai siswa dan mudah diterima siswa, nilai-nilai yang terkandung dalam teks, dan cerita tokoh-tokoh terkenal. Model SETS (Science Environment Technology Society) terbukti efektif dalam pembelajaran menulis teks anekdot (Nopriyanti, 2015).

Salah satu metode pembelajaran yang dapat digunakan untuk mencapai tujuan pembelajaran adalah discovery learning. Metode ini mengajarkan siswa untuk menemukan konsep secara mandiri (Dahar dalam Pradana, 2015; Sunismi, 2015; Aqib, 2014). Metode ini mampu melatih siswa membangun kepecayaan diri (Muhamad, 2017). Discovery learning menitikberatkan pada keaktifan siswa yang dimulai dari menemukan, menyelidiki, dan menentukan simpulan dari hasil penemuan tersebut. Metode ini menempatkan guru hanya sebagai pembimbing dan mengarahkan agar proses pembelajaran berjalan sesuai dengan tujuan yang sudah direncanakan. Druckman \& Ebner (2018:3) menyatakan discovery learning mengacu pada tugas-tugas dimana informasi target harus ditemukan oleh pelajar. Pelajar adalah pusat dari proses pembelajaran.

Dalam discovery learning, siswa belajar secara mandiri tanpa dibantu mendapatkan konsep-konsep mengenai materi pembelajaran. Para peneliti sering menyebut kelompok lain sebagai kelompok discovery karena kurang dibantu selama proses pembelajaran. Sebuah tinjauan literatur menunjukkan bahwa discovery learning terjadi ketika pelajar tidak diberikan informasi target atau pemahaman konseptual dan harus menemukannya secara mandiri dan hanya dengan materi yang disediakan (Alfieri et al., 2011). Discovery learning melibatkan siswa dalam menemukan masalah mereka sendiri dan memecahkannya, dan pada akhirnya mampu membangun konsep yang bermakna. Artinya, metode pembelajaran discovery mengarahkan siswa untuk memahami konsep, makna, dan hubungan, melalui proses yang intuitif (Syafyahya \& Yades, 2019). Metode pembelajaran discovery learning memberikan keleluasaan pada siswa untuk menemukan masalah suatu konsep.

Model discovery learning menitikberatkan pada pengembangan pemahaman konsep dan keterampilan berdasarkan pengalaman nyata. Model discovery learning juga mengungkapkan gambaran suatu kejadian yang harus dijelaskan secara tepat (Mulyani, 2019; Soimin, 2014). Konsep mengenai teks anekdot dan keterampilan menulis teks anekdot dapat dikembangkan kemampuannya melalui proses pembelajaran dengan menggunakan metode discovery learning. 
Berdasarkan uraian di atas, penelitian ini berfokus pada peningkatan kemampuan pengetahuan dan keterampilan siswa pada materi teks anekdot.

\section{METODE}

Metode penelitian adalah tindakan kelas karena mengkaji tentang situasi sosial dengan maksud untuk meningkatkan kualitas tindakan di dalamnya (Elliot dalam Wibawa, 2004). Penelitian ini terbagi menjadi dua siklus yang setiap siklusnya dilakukan dalam dua pertemuan. Penelitian ini dilakukan dalam tiga tahapan pada setiap pertemuannya, yakni: perencanaan (plan), tindakan (do), dan refleksi (see). Adapun pelaksanaannya seperti yang tertulis pada tabel 1. Tahap tindakan dalam penelitian ini adalah penerapan metode discovery learning dalam pembelajaran bahasa Indonesia terhadap materi teks anekdot.

\section{Tabel 1. Jadwal Pelaksanaan Lesson Study Pembelajaran Menulis}

Teks Anekdot

\begin{tabular}{lcccc}
\hline TAHAPAN & \multicolumn{4}{c}{ TANGGAL PELAKSANAAN } \\
\cline { 2 - 5 } \multicolumn{1}{c}{ SIKLUS } & \multicolumn{1}{c}{ Siklus I P1 } & \multicolumn{1}{c}{ Siklus I P2 } & Siklus II P1 & Siklus II P2 \\
\hline Plan & 4 Nov 2017 & 8 Nov 2017 & 11 Nov 2017 & 18 Nov 2017 \\
Do & 6 Nov 2017 & 9 Nov 2017 & 13 Nov 2017 & 20 Nov 2017 \\
See & 6 Nov 2017 & 10 Nov 2017 & 14 Nov 2017 & 24 Nov 2017 \\
\hline
\end{tabular}

Subjek dalam penelitian ini adalah kelas X Multimedia 1 SMK TI Garuda Nusantara Cimahi yang berjumlah 36 siswa. Penelitian ini dilakukan dari tanggal 4 November sampai 16 November 2017. Instrumen yang digunakan dalam penelitian ini adalah lembar observasi aktivitas siswa, LKS, dan soal tes disetiap pertemuannya.

Cara pengumpulan data dalam penelitian ini menggunakan sebuah tes tertulis yang dikerjakan oleh siswa pada setiap pertemuan. Hasil observasi yang diperoleh pada pertemuan pertama akan diolah, dideskripsikan, dan diinterprestasikan yang kemudian akan direfleksikan untuk perbaikan pada pertemuan selanjutnya. Hasil tes yang diperoleh akan menentukan peningkatan siswa sesuai dengan Kriteria Ketuntasan Minimal (KKM) yang telah ditetapkan.

\section{HASIL DAN PEMBAHASAN} tabel 2.

Hasil analisis dalam empat pertemuan dari kedua siklus dapat dilihat pada

Tabel 2. Hasil Pengamatan Aktivitas Siswa Tiap Siklus

\begin{tabular}{lcccc}
\hline Aspek & Siklus 1 P1 & Siklus 1 P2 & Siklus 2 P1 & Siklus 2 P2 \\
\hline Rata-rata & 50.56 & 86.11 & 100 & 68.89 \\
Kategori & Kurang & Baik & Sangat Baik & Cukup \\
Kolaborasi & $70 \%$ & $70 \%$ & $85 \%$ & $90 \%$ \\
Komunikasi & $75 \%$ & $75 \%$ & $80 \%$ & $95 \%$ \\
Kritis & $25 \%$ & $35 \%$ & $60 \%$ & $75 \%$ \\
Kreatif & $25 \%$ & $50 \%$ & $60 \%$ & $70 \%$ \\
\hline
\end{tabular}

Berdasarkan tabel 2 dapat dijelaskan bahwa pada siklus I pertemuan kesatu rata-rata nilai dari 27 siswa hanya 50,56 dengan kategori kurang. Sementara itu, sikap siswa dalam pertemuan ini belum terlalu menonjol. Hal ini terlihat dari 
kolaborasi 70\% (19 siswa), komunikasi 75\% (20 siswa), kritis 25\% (7 siswa), dan kreatif $25 \%$ (7 siswa). Secara umum, dari hasil analisis siswa dalam membedakan anekdot dan humor berada pada kategori kurang.

Hasil analisis siswa pada siklus I pertemuan kedua menunjukkan kenaikan pada hasil pembelajaran. Hal ini terlihat dari rerata siswa yang mengalami kenaikan menjadi 86,11 dengan kategori baik. Terlihat peningkatan dari segi kritis dan kreatif siswa, yakni kritis 35\% atau 9 siswa dan kreatif sebanyak 50\% atau 13 siswa. Secara umum, siswa sudah mampu dalam membedakan anekdot dan humor dengan kategori baik.

Selanjutnya, analisis siswa pada siklus II pertemuan kesatu mengalami kenaikan yang signifikan. Hal ini terlihat dengan rata-rata siswa yakni 100 pada materi menganalisis struktur teks anekdot. Selain itu, dari hasil observasi sikap siswa mengalami kenaikan, yakni kolaborasi 85\% (23 siswa), komunikasi 80\% (22 siswa), kritis dan kreatif sebanyak 60\% (16 siswa). Pada materi ini, hasil belajar siswa terlihat sudah sangat baik dengan hasil yang diperoleh.

Pada siklus II pertemuan kedua siswa mengalami penurunan. Hal ini dapat dilihat dari rata-rata siswa hanya 68,89. Sedangkan, untuk keaktifan siswa mengalami kenaikan sebagai berikut: kolaborasi 90\% (24 siswa), komunikasi 95\% (26 siswa), kritis 75\% (20 siswa), dan kreatif 70\% (19 siswa). Penurunan hasil belajar tersebut disebabkan karena materi pembelajaran yang dianggap sulit oleh siswa dan keterbatasan waktu dalam pembelajaran.

Berdasarkan hasil analisis tersebut, dapat disimpulkan bahwa metode discovery learning dapat meningkatkan pengetahuan dan keterampilan siswa dalam pembelajaran teks anekdot karena menurut Kemendikbud (Muhammad, 2016:12) salah satu kelebihan metode discovery yaitu membantu siswa untuk memperbaiki dan meningkatkan keterampilan-keterampilan dan proses-proses kognitif. Usaha penemuan merupakan kunci dalam proses ini, hal ini bergantung pada cara belajar seorang siswa.

\section{Pembahasan}

Penelitian ini merupakan penelitian yang terdiri atas 2 siklus yang terbagi menjadi 4 pertemuan. Observer yang terdapat dalam penelitian sebanyak 4 observer dan 1 guru model. Instrument dalam penelitian ini berupa tes dan hasil observasi. Tes yang diberikan berkaitan dengan pengetahuan dan kemampuan siswa mengenai teks anekdot. Sementara itu, observasi dilakukan untuk melihat perubahan sikap siswa selama pembelajaran.

Berikut ini tabel 3 adalah hasil tes yang dilakukan selama pembelajaran 2 siklus dan 4 pertemuan.

Tabel 3 Hasil Tes Keterampilan Menulis Teks Anekdot

\begin{tabular}{ccccc}
\hline Tahapan & Siklus I P1 & Siklus I P2 & $\begin{array}{c}\text { Siklus II } \\
\text { P1 }\end{array}$ & $\begin{array}{c}\text { Siklus II } \\
\text { P2 }\end{array}$ \\
\hline Rata-rata nilai & 50,56 & 86,11 & 87,00 & 87,3 \\
\hline
\end{tabular}

Tabel 3 menunjukkan bahwa pembelajaran menulis teks anekdot dengan menggunakan metode discovery learning mengalami peningkatan rata-rata nilai pada setiap siklus dan setiap pertemuan. Peningkatan yang sangat signifikan yaitu pada siklus I pertemuan 2 dengan rata-rata nilai dari 50,56 menjadi 86,11. Peningkatan ini dipengaruhi oleh upaya guru dalam menyiapkan proses pembelajaran setelah melalui tahap evaluasi pada siklus I pertemuan 1. Dengan demikian, kemampuan siswa baik kemampuan pengetahuan maupun keterampilan 
akan mengalami peningkatan apabila dalam pembelajaran memperhatikan metode pembelajaran yang digunakan, materi yang disampaikan, dan media yang digunakan.

Analisis tersebut sesuai dengan pendapat Sardiman (Khasanah, 2014) bahwa media pembelajaran memiliki kegunaan mengatasi sikap pasif siswa. Penggunaan media mampu mempengaruhi semangat belajar siswa sehingga siswa lebih aktif belajar. Demikian juga dengan pemilihan metode pembelajaran dengan system diskusi memiliki pengaruh terhadap aktivitas siswa. Hal ini sejalan dengan pendapat Kurnadi (Prihatini, 2017) menyampaikan bahwa diskusi kelas mampu meningkatkan siswa dalam belajar

Berdasarkan hasil analisis dari kedua siklus tersebut dapat dijelaskan bahwa metode discovery learning mampu meningkatkan pengetahuan dan keterampilan siswa dalam pembelajaran teks anekdot. Siklus I pertemuan 1 pembelajaran dimulai dengan menyampaikan tujuan pembelajaran dan kegiatan pembelajaran yang akan dilakukan. Selanjutnya siswa diminta mengamati dan memahami konsep teks anekdot. Siswa diharuskan menulis teks anekdot berdasarkan tema yang ditentukan sendiri.

Berdasarkan hasil pengamatan dan proses penilaian pada siklus I pertemuan pertama, hasil tes siswa masih di bawah KKM dengan rata-rata kelas 50,56. Hal tersebut dipengaruhi oleh beberapa faktor. Proses pembelajaran yang menggunakan metode discovery learning belum berjalan dengan baik. Kesiapan siswa saat pembelajaran masih kurang. Hal tersebut dapat dilihat dari beberapa siswa yang masih tidak memperhatikan guru saat menyampaikan materi. Selain itu, masih banyak siswa yang tidak bisa berkolaborasi dengan teman kelompoknya dalam memecahkan persoalan yang diberikan oleh guru model. Media di kelas pun masih kurang, karena in focus yang pada awalnya akan digunakan dalam proses pembelajaran tidak ada sehingga siswa jenuh dalam mengikuti pembelajaran.

Setelah melihat hasil pada tes pertama yang masih kurang memenuhi target, maka dilakukan beberapa perbaikan. Perlu adanya pengelolaan pembelajaran yang dapat membangun kesiapan siswa dalam belajar. Siswa diharapkan mampu menemukan konsep dan keterampilan dalam menulis teks anekdot. Metode discovery learning adalah metode yang dapat membangun kemandirian siswa dalam belajar. Hal ini sejalan dengan pendapat Maarif (2016) bahwa discovery learning terjadi ketika siswa melakukan proses mental, seperti mengamati, mengklasifikasikan, membuat dugaan, mengukur, menjelaskan, menarik kesimpulan, dan sebagainya untuk menemukan beberapa konsep atau prinsip.

Hasil pengamatan terhadap aktivitas dan partisipasi siswa dalam kelas, pada siklus I pertemuan pertama ini untuk kolaborasi sudah terlihat namun belum seluruh siswa yaitu 70\%. Siswa juga sudah mampu berkomunikasi dengan teman satu kelompok dalam menyelesaikan masalah yaitu 75\%. Namun untuk berpikir kritis masih rendah yaitu $25 \%$, karena masih banyak siswa yang tidak dapat membuat teks anekdot dengan cepat, rata-rata mereka berpikir dahulu dan bahkan melihat ke teman dekatnya. Demikian juga kemampuan kreatifnya masih rendah yaitu $25 \%$, artinya banyak siswa yang tidak bias menyampaikan ide-ide kreatifnya mengenai teks anekdot yang akan ditulis.

Pada pertemuan kedua ini, berdasarkan hasil evaluasi pada pertemuan pertama maka diperlukan ada beberapa penambahan aktivitas dan proses pembelajaran. Guru melakukan ice breaking untuk menyiapkan anak dalam 
menerima materi. Selain itu, guru juga memberikan nama kelompok beserta topi pada setiap kelompok siswa. Dalam proses pembelajarannya guru banyak memberikan contoh dari teks anekdot dan humor. Selain itu, hasil diskusi setiap kelompok dipresentasikan di depan kelas dan penampilan yel-yel kelompok diakhir persentasi. Pembelajaran tersebut lebih baik dibandingkan dengan pertemuan pertama. Hal tersebut dapat dilihat dari berkurangnya jumlah siswa yang tidak memperhatikan guru. Selain itu, siswa sudah mampu berkolaborasi dengan temannya. Walau masih ada beberapa siswa yang pasif dan tidak bisa mengikuti pembelajaran. Meskipun begitu, hasil tes siswa pada pertemuan ini mengalami peningkatan. Semua siswa yang mengikuti tes memperoleh nilai di atas KKM sehingga rata-rata kelasnya meningkat yakni 86,11.

Hasil pengamatan partisipasi siswa dalam kelas pada pertemuan kedua ini sudah nampak ada perubahan sedikit terutama pada aspek berpikir kritis dan kreatifnya. Ketika diberi tugas membuat teks anekdot, sebanyak 35\% (kritis) dan $50 \%$ (kreatif) siswa mampu menentukan bentuk tulisan mengenai teks anekdot dengan cepat.

Siklus II pertemuan 1 pembelajaran dimulai dengan terlebih dahulu dibentuk kelompok yang dipilih secara acak dan heterogen. Selanjutnya guru menyampaikan tujuan pembelajaran dan kegiatan pembelajaran yang akan dilakukan. Setiap kelompok diberikan contoh teks anekdot dan siswa diminta menganalisis teks anekdot tersebut berdasarkan strukturnya.

Berdasarkan hasil pengamatan dan analisis data pada siklus II pertemuan pertama, materi yang diajarkan berbeda. Pada pertemuan ini materi yang disampaikan adalah struktur teks anekdot. Pembelajaran kali ini dibantu dengan media in focus sehingga siswa lebih memperhatikan apa yang disampaikan oleh guru model. Posisi kelompok siswa diatur kembali sehingga para siswa mampu berdiskusi dengan anggotanya secara lebih baik. Hasil tes pada pertemuan ini mengalami peningkatan. Seluruh siswa yang mengikuti tes memperoleh nilai di atas KKM yaitu sebesar 87,00. Selain itu, terjadi perubahan sikap belajar siswa. Siswa terlihat lebih siap dalam mengikuti pembelajaran. Seluruh siswa mampu berkomunikasi dengan guru dan temannya.

Hasil pengamatan aktivitas dan partisipasi siswa pada pertemuan ini sudah lebih baik dibanding pada siklus I. Kegiatan kolaborasi sudah mampu dilakukan oleh siswa dengan teman-teman satu kelompoknya yaitu sebesar $85 \%$. Demikian juga komunikasi siswa dengan temannya dan guru sudah lebih aktif, Mereka banyak yang bertanya kepada guru terkait konsep dan struktur serta kaidah kebahasaan teks anekdot dengan presentasi $80 \%$. Kegiatan berpikir kritis dan kreatif juga mengalami peningkatan yang sangat signifikan yaitu sebesar $60 \%$.

Pada siklus II pertemuan kedua, materi yang diajarkan lebih sulit lagi. Materi tersebut adalah menulis teks anekdot. Pada pembelajaran ini, sebelum siswa membuat sebuah teks, guru model memberikan materi bagaimana membuat teks anekdot dan memberikan beberapa contoh teks. Untuk tes pada pertemuan ini, guru model memberikan beberapa gambar yang sesuai dengan tema yang telah ditentukan sebelumnya. Hasil pada tes ini, siswa mengalami peningkatan kemampuan. Siswa yang mengikuti tes pada siklus II pertemuan kedua yaitu 25 siswa dari 27 siswa. Soal latihan yang diberikan pada pertemuan ini lebih sulit disbanding pertemuan sebelumnya yaitu siswa harus memahami soal pengetahuan dan mengerjakan soal menulis teks anekdot dengan tema yang beragam. Pada hasil akhir pertemuan ini diperoleh bahwa siswa mengalami peningkatan 
kemampuan pengetahuan dan keterampilan menulis teks anekdot. Dengan demikian, 25 orang siswa memperoleh nilai melebihi dari KKM yang sudah ditentukan yaitu 87,3.

Peningkatan jumlah siswa yang memenuhi KKM tersebut dipengaruhi oleh proses pembelajaran yang dilakukan di kelas. Perbaikan di setiap siklusnya mempengaruhi pemahaman siswa tentang materi tersebut sehingga nilai yang diperoleh meningkat. Hal tersebut disebabkan oleh beberapa faktor. Pertama, siswa lebih memperhatikan penjelasan guru disaat guru model menggunakan media infocus sehingga materi yang disampaikan mudah dipahami oleh siswa. Kedua, tingkat kesulitan materi juga mempengaruhi hasil tes siswa. Hal tersebut dibuktikan dengan jumlah siswa yang memenuhi KKM pada tes keempat hanya 15 siswa dari 35 siswa yang mengikuti. Setelah diteliti, ternyata tingkat kesulitan materi lebih tinggi dibandingkan dengan materi sebelumnya. Selain itu, waktu tes yang diberikan terlalu singkat sehingga siswa tidak maksimal dalam mengerjakan tes. Selain menggunakan tes, nontes juga dilakukan pada penelitian ini untuk mengetahui peningkatan keaktifan belajar siswa.

Penelitian kolaboratif membutuhkan dukungan instruksional yang inovatif dan berpusat pada siswa (Van Joolingen et al., 2005). Hal ini selaras dengan hasil pengamatan terhadap aktivitas dan partisipasi siswa pada pertemuan terakhir ini menunjukkan perubahan yang sangat baik. Kolaborasi dan komunikasi antarsiswa sudah dapat dilakukan dengan sangat baik. Siswa mampu berkolaborasi dan berkomunikasi dengan temannya dalam menghasilkan teks anekdot yang baik serta siswa merencanakan kegiatan presentasi yang akan dilakukan di depan kelas. Demikian juga kagiatan berpikir kritis dan kreatifnya mampu dilakukan dalam pembelajaran dalam menyusun teks anekdot.

Tabel 4. Perkembangan Proses Pembelajaran

\begin{tabular}{|c|c|}
\hline Tahapan & Perkembangan proses pembelajaran \\
\hline Siklus I P 1 & $\begin{array}{l}\text { a. Pembelajaran masih konvensional, guru menjelaskan } \\
\text { materi pembelajaran } \\
\text { b. Siswa mengamati konsep teks anekdot }\end{array}$ \\
\hline Siklus I P 2 & $\begin{array}{l}\text { a. Pembelajaran diawali dengan guru memberikan contoh } \\
\text { teks anekdot } \\
\text { b. Setiap kelompok diberi nama khas masing-masing } \\
\text { kelompok } \\
\text { c. Hasil keria kelompok dipresentasikan di depan kelas }\end{array}$ \\
\hline Siklus II P 1 & $\begin{array}{l}\text { a. Menggunakan media pembelajaran infokus } \\
\text { b. Anggota kelompok diatur kembali } \\
\text { c. Setiap kelompok mempresentasikan hasil kerjanya di } \\
\text { depan kelas }\end{array}$ \\
\hline Siklus & $\begin{array}{l}\text { a. Siswa belajar mandiri dalam memahami teks anekdot } \\
\text { b. Siswa berkelompok yang disusun secara acak/heterogen } \\
\text { c. Menggunakan infokus } \\
\text { d. Guru memberikan contoh-contoh teks anekdot } \\
\text { e. Siswa mempresentasikan hasil kerja menyusun teks } \\
\text { anekdot di depan kelas dengan memerankan tokoh dalam } \\
\text { teks. }\end{array}$ \\
\hline
\end{tabular}


Tabel 4 yang memperlihatkan perkembangan proses pembelajaran menulis teks anekdot. Berdasarkan observasi yang dilakukan dapat diketahui bahwa siswa mengalami perubahan sikap secara berkala. Dengan demikian, dapat disimpulkan bahwa pengajaran menulis teks anekdot dengan menggunakan metode discovery learning telah berhasil meningkatkan kemampuan pengetahuan dalam materi teks anekdot. Namun, untuk keterampilan menulis teks anekdot masih kurang karena tingkat kesulitan materi dan waktu yang diberikan tidak mencukupi. Selain itu, penelitian ini dapat mengubah perilaku siswa kearah yang lebih positif dalam proses pembelajaran.

\section{SIMPULAN}

Penerapan metode discovery learning mampu mengembangkan pengetahuan siswa tentang teks anekdot dengan adanya peningkatan nilai rerata dari 50,56 menjadi 86,11. Demikian juga untuk keterampilan menulis teks anekdot yang mengalami peningkatan nilai sebesar 87,3. Peningkatan kemampuan pengetahuan dan keterampilan menulis teks anekdot sangat dipengaruhi oleh kepiawaian guru dalam mengelola pembelajaran yang menarik. Upaya yang dilakukan guru pada setiap siklus berbeda-beda. Dimulai dari pembagian kelompok, menciptakan permainan dalam pembelajaran, dan penggunaan media yang menarik. Discovery learning memberikan kesempatan kepada siswa untuk berpartisipasi aktif, berkolaborasi, berkomunikasi, berpikir kritis, dan menghasilkan kreativitas dalam pembelajaran.

\section{UCAPAN TERIMA KASIH}

Kami sampaikan terima kasih kepada SMK TI Garuda dan IKIP Siliwangi yang telah memberi izin untuk melakukan penelitian ini.

\section{DAFTAR PUSTAKA}

Agustina, Y. (2020). Meningkatkan Kemampuan Menganalisis Struktur Teks Anekdot dengan Menggunakan Media Video Pembelajaran pada Siswa Kelas X SMK SWASTA AL MA'SHUM. Jurnal Penelitian, Pendidikan Dan Pengajaran, 1(3), 200 - 208.

Alfieri, L., Brooks, P. J., Aldrich, N. J., \& Tenenbaum, H. R. (2011). Does Discovery-Based Instruction Enhance Learning? Journal of Educational Psychology, 103(1), 1 - 18. https://doi.org/10.1037/a0021017

Aqib, Z. (2014). Model-model, Media, dan Strategi Pembelajaran Kontekstual (Inovatif). Bandung: Yrama Widya.

Azis, A. (2012). Menulis Poster dan Slogan melalui Penerapan Metode Pembelajaran Berbasis Masalah (Problem Based Learning) Suatu Alternatiff Peningkatan Keterampilan Menulis. Semantik, 1(1), 65 - 74.

Dewy, R. T. (2016). Pembelajaran Menulis Cerpen dengan Menggunakan Teknik Transformasi Naskah Drama pada Siswa Kelas X MA Uswatun Hasanah Padalarang Tahun Ajaran 2015. STKIP Siliwangi.

Druckman, D., \& Ebner, N. (2018). Discovery Learning in Management Education: Design and Case Analysis. Journal of Management Education, 42(3), 347 - 374. https://doi.org/10.1177/1052562917720710

Heriawan, A. (2012). Metodologi Pembelajaran Kajian Teoritis Praktis. LP3G.

Khasanah, N. U. (2014). Pengaruh Metode Mengajar dan Media Pembelajaran Terhadap Motivasi Belajar Siswa Kelas X Program Keahlian Administrasi 


\section{Indonesian Language Education and Literature \\ e-ISSN: 2502-2261 \\ http://www.syekhnurjati.ac.id/jurnal/index.php/jeill/ \\ Vol. 6, No. 1, Desember 2020, $36-46$}

Perkantoran SMK Negeri 1 Yogyakarta.

https://doi.org/10.1016/j.gaitpost.2018.03.005

Kusnadi. (2017). MenganalisissTeks Anekdott dengan Menggunakann Metode Paradigmaa Kritiss pada Siswa Kelas X SMK Pakuan Lembang Tahun Pelajaran 2016/2017. Universitas Pasundan.

Maarif, S. (2016). Improving junior high school students' mathematical analogical ability using discovery learning method. International Journal of Research in Education and Science (IJRES), 2(1), 114 - 124.

Muhamad, N. (2017). Pengaruh Metode Discovery Learning untuk Meningkatkan Representasi Matematis dan Percaya Diri Siswa. Jurnal Pendidikan UNIGA, $10(1), 9-22$.

Mulyani, R. (2019). Studi Komparasi: Discovery Learning Vs Guided Discovery Learning Terhadap Peningkatan Pemahaman Konsep Fisika 10 Kata. Gravity: Jurnal Ilmiah Penelitian Dan Pembelajaran Fisika, 5(1), 39 - 48. https://doi.org/10.30870/gravity.v5i1.5210

Nopriyanti, E. (2015). Penerapan Model SETS (Science Environment Technology Society dalam Pembelajaran Menulis Teks Anekdot. Universitas Pendidikan Indonesia.

Permadi, dkk. (2018). Development of Anecdote Text Writing Teaching Materials Based on Process Approach For Student Class X SMA Negeri 1 STABAT. International Journal of Education Learning and Development, 6(8), 71 78.

Pradana, P. G., Artawan, G., \& Darmayanti, I. A. M. (2015). Pembelajaran Menulis Teks Prosedur dengan Metode Discovery Learning di Kelas X MIA 22 SMA Negeri 1 Blahbatuh. Jurnal Pendidikan Bahasa Dan Sastra Indonesia Undiksha, 3(1), 1 - 12.

Prihatini, E. (2017). Pengaruh Metode Pembelajaran Dan Minat. Formatif : Jurnal Ilmiah Pendidikan MIPA, 7(2), 171 - 179.

Puspitasari, P., \& Supriatna, E. (2017). Model Pembelajaran Kontekstual Berbasis Pengalaman dalam Pembelajaran Menulis Teks Anekdot pada Kelas X SMA Negeri 20 Bandung. Jurnal P2M STKIP Siliwangi, 3(1), 39 - 44.

Rahmayanti, D., Martha, I. N., \& Wisudariani, N. R. (2015). Pembelajaran Menulis Teks Anekdot pada Mata Pelajaran Bahasa Indonesia dalam Kurikulum 2013 di Kelas X.A Akuntansi SMK Negeri 1 Singaraja. Pendidikan Bahasa Dan Sastra Indonesia Undiksha, 3(1), 1 - 12.

Sholekah, L. A. (2016). Peningkatan Keterampilan Menulis Teks Anekdot Bermuatan Kesantunan Berbahasa Menggunakan Model Pembelajaran Berbasis Masalah (Problemm Based Learning) pada Siswa Kelas X MIA-4 SMA Negeri 1 Grobogan. Jurnal Pendidikan Bahasa Dan Sastra Indonesia, $5(1), 42-50$.

Sobari, T. (2012). Penerapan Teknik Siklus Belajar dalam Pembelajaran Menulis Laporan Ilmiah Berbasis Vokasional di SMK. Jurnal Semantik, 1(1), 17-41.

Soimin, A. (2014). Model Pembelajaran Inovatif dalam Kurikulum 2013. Ar-ruz Media.

Suherli, K. (2017). Buku Guru: Bahasa Indonesia. Jakarta: Kemendikbud.

Sunismi. (2015). Developing Guide Discovery Learning Material Using Mathematics Mobile Learning Application As An Alternative Mediam For The Students Calculus II. Cakrawala Pendidikan, XXXIV(3), 334 - 346.

Syafyahya, L., \& Yades, E. (2018). Discovery Learning And Small Group 
Discussion In Lexicology Education. Proceedings "Improving Educational Quality Toward International Standard" 4 September 2018, Universitas Andalas Padang, 52-56. https://doi.org/10.5220/0008679300520056

Van Joolingen, W. R., De Jong, T., Lazonder, A. W., Savelsbergh, E. R., \& Manlove, S. (2005). Co-Lab: Research and development of an online learning environment for collaborative scientific discovery learning. Computers in Human Behavior, 21(4), 671 - 688. https://doi.org/10.1016/j.chb.2004.10.039

Wardani, E. D., Rustono, M., \& Nuryatin, A. (2018). Structure and Contextual Meaning Analysis of Anecdote Text with Character and Local Wisdom as an Alternative to Selection of Teaching Materials for Indonesian in Senior High School. 247(Iset), 128 - 131. https://doi.org/10.2991/iset-18.2018.27

Wardani, S. R., Fuady, A., \& Andayani. (2016). Peningkatan Keaktifan dan Kemampuan Menulis Teks Anekdot dengan Menggunakan Model Pembelajaran Make A Match Pada Siswa Kelas X SMK. Basastra, 4(1), $168-182$.

Wibawa, B. (2004). Penelitian Tindakan Kelas. Depdiknas Dikti.

Woi, P. L. J., Burhanuddin, D., \& Sinaga, M. (2019). Implikatur pada Teks Anekdot dalam Buku Teks Pelajaran Bahasa Indonesia SMA Kelas X. Jurnal Tuah, 1(1), $34-42$.

Zain, S., R. Nurdin, M., Kasan, \& Suhartini. (2017). Efektivitas Teknik Pengandaian Diri dalam Pembelajaran Menulis Cerita Pendek. Retorika, 10(2), 100-105. https://doi.org/10.26858/retorika.v 